\title{
Research and restocking of wheat varieties to pathogens of especially dangerous fungal diseases
}

\author{
$Y u . V$. Zeleneva $^{1,2, *}$, and $V . P$. Sudnikova ${ }^{1}$ \\ ${ }^{1}$ I. V. Michurin Federal Research Center, Tambov, Russian Federation \\ ${ }^{2}$ All-Russian Institute of Plant Protection, Saint Petersburg, Pushkin, Russian Federation
}

\begin{abstract}
Based on the results of immunological assessments and rejection of the material by phenotype, 327 sources and 79 donors of immunity were selected from spring wheat, 27 and 23 from winter wheat, respectively. Applying PCR diagnostic method, Lr genes were found in the selected samples of spring wheat. Screening revealed the presence of the following genes in the studied samples. They are $\operatorname{Lr} 9, \operatorname{Lr} 19, \operatorname{Lr} 24, \operatorname{Lr} 34, \operatorname{Lr} 1, \operatorname{Lr} 10$, $L r 20$ and Lr26. Within selection samples of the Central Russian branch, the prevalence of lines with the Lr19 gene in combination with inefficient genes $\operatorname{Lr} 10, \operatorname{Lr} 20$ and $\operatorname{Lr} 26$ was revealed. Spring soft wheat cultivation lines adapted to zonal conditions have been developed, combining in their phenotype resistance to the main phytopathogens of the region with valuable economic properties. In 2019, a variety of spring soft wheat in memory of Plahotnik was transferred to the State Export Commission for testing.
\end{abstract}

\section{Introduction}

For the Central Black Earth Region, it is a promising way to create a collection of sources and genetic donors of resistance of samples of commercial winter and spring wheat species for particularly dangerous diseases caused by parasitic fungi. Crop breeders, while developing their programs, consider the introduction of new effective and different resistance genes into varieties [1,2]. Findings of screening of spring and winter wheat collections carried out by Russian researches indicate that resistant wheat samples to Septoria leaf spot, brown rust, dust and stinking smut are relatively rare $[2,3]$. Particularly rare are samples with group resistance to several phytopathogens [4]. Thus, it is essential to study the effectiveness of genes that determine resistance to pathogens; to substantiate the qualitative composition of the biomaterial that provides an objective assessment of host plants.

The objective of the work was to study and refill the collection of sources and donors of resistance for the selection of wheat for group and (or) complex resistance to Septoria leaf spot, brown rust, dust and stinking smut.

\footnotetext{
*Corresponding author: zelenewa@mail.ru
} 


\section{Materials and methods}

The object of research was varieties of commercial types of spring and winter wheat, specimens from the VIR collection, as well as original breeding lines derived from crossing non-district donors with the best zoned varieties. The tests were performed in field infectious nurseries of brown rust, Septoria leaf spot, dust and stinking smut. For inoculation, the biomaterial that most fully reflected the pathogenic properties of natural populations was used. The classification of the types "resistance-susceptibility" was considered according to the international scales recommended by the methodological guidelines [5].

Sowing was performed in the optimal agrotechnical terms for the crop, accepted in the zone. The forecrop is a complete fallow. The area of plots under each variety is $0.6-1.0 \mathrm{~m}^{2}$.

As a control, we used highly susceptible varieties for each pathogen-indicators that were located through 20 numbers: Prokhorovka (Septoria leaf spot), Saratovskaya 42 (brown rust), Saratovskaya 60 (dust smut) and Estivum 66 (stinking smut).

For indentification of Lr-genes, collectible varieties and original breeding lines were chosen, combining resistance to brown rust with a complex of other positive signs and properties. Molecular markers of fifteen Lr genes were applied: Lr1 [6], Lr9 [7], Lr10 [8], Lr19 [9, 10], Lr20 [11], Lr21 [12], Lr24 [13, 14], Lr26 [15], Lr28 [15], Lr29 [16], Lr34 [17], $\operatorname{Lr} 35$ [18], Lr37 [19], Lr39(=Lr41) [20, 21], Lr47 [21].

Wheat DNA was isolated according to the methodological guidliness of Dorokhova D. B. and Kloke E. [22]. DNA amplification was performed in a reaction mixture according to the procedures suggested by the authors. These studies were carried out on the experimental basis of the Laboratory of Mycology and Phytopathology of the VIZR together with Elena Ivanovna Gultyaeva, Doctor of Biology, leading researcher.

Statistical data processing was carried out using "StatSoft STATISTICA 10".

\section{Results and discussion}

29,273 samples of winter soft wheat and spring soft and hard wheat were studied in field infectious nurseries (Septoria leaf spot, dust and stinking smut and brown rust).

Based on the findings of immunological evaluations and rejection of the material by phenotype, 327 sources and 79 donors of resistance were chosen among spring wheat, while 27 and 23 donors were selected for winter wheat, respectively. During the selections, not only the intensity of disease damage was assessed, but also valuable economic features that are also required for the inclusion of samples in breeding programs. Each year, the employees of the plant immunity laboratory send out breeding materials to specialized research institutions located on the territory of the Central Black Earth Region of the Russian Federation and the Volga region. The sources of spring wheat resistance to the following phytopathogens were chosen:

- brown rust - 72, these include complex hybrids under the branch catalog numbers 32754, 33403 (Brazil); 35061 (Spain); 33754 (Colombia); 30287, 32992 (Mexico); varieties of domestic selection 31684, 34900, 54208, Russia, etc.

- Septoria leaf spot - 70, including: 37791, 31388-45, 31349, 31351 (USA); 33815, 33817, 34646 (Mexico); 31819, 31865, 32265 (SIMMIT); 35012 (Peru); 54208 (Russia), etc.

- brown rust and Septoria leaf spot - 43, including 35061 (Spain); 31641 (Canada), 34859, 30104, 31917 (Mexico), 32754, 33403, 32650 (Brazil), 54208 (Russia), etc.

— dust smut - 43: 31684 (Georgia); 61292 (Belarus); 30774, 31942, 31945 (Brazil); 31641, 39441 (Canada), Tulaykovskaya 100, Voevoda, Albidum 29, KVS Torridon, KVSAvilon (Russia), etc.

- stinking smut - 90, including among winter wheat varieties, the varieties Mera, Mironovskaya 65, Tarasovskaya 97 are practically resistant; samples from the USA: 38488, 
Nebred; 44390, Omar; 44817, Omacha. Among the samples of spring wheat, a stable reaction was shown by varieties: 31985, 32581, 32503, (SIMMIT); 17729 (France); 49270 (USA); 47006 (Peru), Bezenchukskaya 182, Kurskaya 2038, Simbirtsit, Orenburgskaya 10, Valentina.

The selection material with complex stability has a special value. The following varieties can be recommended for inclusion in breeding programs:

— to brown rust and dust smut: 426110 (Mexico), etc.;

— to Septoria leaf spot and brown rust: 54208 (Russia); 35061 (Spain); 32754, 33403 (Brazil), etc.

- to Septoria leaf spot and dust smut: 30774, 32599 (Brazil); 31622, Canada, etc.;

— to brown rust and dust smut: 31942, 31945 (Brazil); 30011 (Canada), etc.;

— to Septoria leaf spot, dust and stinking smut: 33333 (India); 49441 (Canada), etc.;

- to dust smut, Septoria leaf spot and brown rust: 31641 (Canada); 34859, 31917, 34646 (Mexico), etc.;

- to Septoria leaf spot, brown rust and stinking smut: 32662 (Mexico), etc.;

- to brown rust, Septoria leaf spot, dusty and stinking smut: 32650 (Brazil), etc.

Donors of spring wheat disease resistance:

- to brown rust - 18, among them: Agis 503, ANK 3, Novosibirsk 44 (Lr19, Lr9), Lubninka, Lebedushka ( $\operatorname{lr} 19$, $\operatorname{Lr} A g)$, Udacha (Lr9), Sibirskaya 155, Tertia $(\operatorname{Lr} 19, \operatorname{Lr} 9)$, Tulaykovskaya 100 (Lr38), ITZ (LrTt1Tt2), Ekada 6 (Lr9), Estivum 56, Estivum 60, Estivum 509 (LrAg), Estivum 520, Estivum 527, Estivum 607, Estivum 611;

— to Septoria leaf spot - 24: 30306, 31310-2 (USA); 33907-1-2 (Colombia); 33809-76 (Mexico); Estivum 476, Lutescens 620, Tertia, Sibirskaya 155, Estivum 529, Estivum 614, etc.;

- to dust smut - 21, among them are Preston, Hussar, CI 12033 (USA); Nore (Canada); Bashkirskaya 4, Bezenchukskaya 98, Bashkirskaya 11, Bulyak, Zhigulevskaya, Dalnevostochnaya, Amurskaya 75, Tambovchanka, Cooperatorka, etc.;

— to stinking smut - 23 including 468541 (Mexico); 33712, 31986 (USA); Tambovchanka, Zhigulevskaya, Estivum 527, Pyramida, Estivum 56, Lada, etc.

Donors of winter wheat resistance to pathogens:

- to brown rust -15: Transfer, Caldwel, Riley, Arthur 71, McNair 1813 ( $\operatorname{Lr} 9)$, Bleuboy (Lr1, Lr24, Sr 24), Bleuboy2 (Lr1, Lr10, Lr24, Sr24), Fox (Lr10, Lr24), Osage (Lr24), Parker 76 (Lr10, Lr24, Sr24), Avon (Lr23, LrH), Parker (Lr10, Lr24, LrPar), Kryzhina (Lr10, Lr26, Lr34), Nemchinovskaya 17, Nemchinovskaya 24 (Lr19).

- to stinking smut - 8: Rio $\left(B t_{6}\right)$, Nebred, Omacha $\left(B t_{4}\right)$, Nugaines, MacCall $\left(B t_{1}, B t_{4}\right)$, Colorow $\left(B t_{1}, B t_{3}, B t_{4}\right)$, Colombia, Burt $\left(B t_{1}, B t_{4}, B t_{6}\right)$. Among these specimens, the last four donors containing several effective Bt genes in the genotype may be of undisputed value for breeding.

In 2020, the rare winter wheat varieties of the VIR collection were assessed for Septoria leaf spot against an artificial infectious background. All 30 samples of rare wheat species submitted in this study proved to be resistant (table 1).

Table 1. Immunological features of rare winter wheat varieties from the VIR collection for Septoria leaf spot.

\begin{tabular}{|l|l|c|c|}
\hline $\begin{array}{l}\text { VIR } \\
\text { Catalog } \\
\text { No. }\end{array}$ & Variety & $\begin{array}{c}\text { Grade of } \\
\text { Septoria } \\
\text { leaf spot } \\
\text { lesion, } \\
\%\end{array}$ & $\begin{array}{c}\text { Resistance } \\
\text { type }\end{array}$ \\
\hline $\mathrm{k}$ & T. compactum vav. Fetissovi, Turkmenistan & 0 & $\mathrm{RR}^{1}$ \\
\hline 13579 & & 0 & \\
\hline
\end{tabular}




\begin{tabular}{|c|c|c|c|}
\hline $\begin{array}{l}\mathrm{k} \\
45824\end{array}$ & T. compactum vav. Icternum, Pakistan & 20 & $\mathrm{R}^{2}$ \\
\hline $\begin{array}{ll}\mathrm{k} \\
62466 \\
\end{array}$ & $\begin{array}{l}\text { Local (SY-84-135-79) T. urartuvav. Spontaneorubrum, } \\
\text { Syria }\end{array}$ & 5 & RR \\
\hline $\begin{array}{l}\mathrm{k} \\
62469 \\
\end{array}$ & $\begin{array}{l}\text { Local (SY-84-135-94) T. urartuvav. Spontaneorubrum, } \\
\text { Syria }\end{array}$ & 5 & $\mathrm{RR}$ \\
\hline $\begin{array}{ll}\mathrm{k} \\
62473\end{array}$ & Local (SY-84-135-117) T. urartuvav. Spontaneorubrum, & 5 & $\mathrm{RR}$ \\
\hline $\begin{array}{ll}\mathrm{k} \\
62475 \\
\end{array}$ & Local (SY-84-135-123) T. urartuvav. Spontaneorubrum, & 5 & $\mathrm{RR}$ \\
\hline $\begin{array}{l}\mathrm{k} \\
62479\end{array}$ & Local (SY-84-135-153) T. urartuvav. Spontaneorubrum, & 5 & R R \\
\hline $\begin{array}{l}\mathrm{k} \\
62483 \\
\end{array}$ & Local (MSYMNR 8809) T. urartuvav. Nigrum, Syria & 5 & $\mathrm{RR}$ \\
\hline $\begin{array}{ll}\mathrm{k} \\
39098 \\
\end{array}$ & T. araraticumvav. Thumanianii, Azerbaijan & 5 & $\mathrm{RR}$ \\
\hline $\mathrm{k} 3162$ & 7 T. araraticumvav. Thumanianii, Armenia & $5 \%$ & $\mathrm{RR}$ \\
\hline $\begin{array}{ll}\mathrm{k} \\
58667\end{array}$ & T. araraticumvav. Thumanianii, Armenia & 10 & $\mathrm{RR}$ \\
\hline $\begin{array}{l}\mathrm{k} \\
18403\end{array}$ & T. boeoticumvav. Fuscum, Turkey & 5 & $\mathrm{RR}$ \\
\hline $\begin{array}{ll}\mathrm{k} \\
27147 \\
\end{array}$ & T. boeoticumvav. Thaoudar, Turkey & 10 & $\mathrm{RR}$ \\
\hline $\begin{array}{l}\mathrm{k} \\
27161\end{array}$ & T. boeoticumvav. Fuscum, Turkey & 10 & $\mathrm{RR}$ \\
\hline $\begin{array}{ll}\mathrm{k} \\
61033 \\
\end{array}$ & T. boeoticumvav. Albinigrum, boeoticum, Iran & 10 & RR \\
\hline $\begin{array}{ll}\mathrm{k} \\
61036 \\
\end{array}$ & T. boeoticumvav. Gegadiricum, vividifuscum, Iran & 10 & $\mathrm{RR}$ \\
\hline $\begin{array}{l}\mathrm{k} \\
61038 \\
\end{array}$ & $\begin{array}{l}\text { T. boeoticumvav. Albinigrescens, bicolor, biarpurunivir, } \\
\text { Turkey }\end{array}$ & 5 & $\mathrm{RR}$ \\
\hline $\begin{array}{ll}\mathrm{k} \\
61040 \\
\end{array}$ & T. boeoticumvav. Fuscum, Iran & 0 & RR \\
\hline $\begin{array}{l}\mathrm{k} \\
61045 \\
\end{array}$ & T. boeoticumvav. Balaclavicum, buluchevskayae, Iran & 0 & $\mathrm{RR}$ \\
\hline $\begin{array}{ll}\mathrm{k} \\
61046 \\
\end{array}$ & $\begin{array}{l}\text { T. boeoticumvav. Abovjani, thaoudar, vividifuscum, } \\
\text { Turkey }\end{array}$ & 0 & RR \\
\hline $\begin{array}{ll}\mathrm{k} \\
28191 \\
\end{array}$ & T. machavav. Palaeoimereticum, Georgia & 0 & $\mathrm{RR}$ \\
\hline $\begin{array}{l}\mathrm{k} \\
28194\end{array}$ & T. machavav. Subletshchumicum, Georgia & 0 & $\mathrm{RR}$ \\
\hline $\begin{array}{ll}\mathrm{k} \\
29577 \\
\end{array}$ & T. machavav. Subletshchumicum, Georgia & 0 & $\mathrm{RR}$ \\
\hline $\begin{array}{ll}\mathrm{k} \\
31686 \\
\end{array}$ & T. machavav. Palaeoimereticum, Georgia & 5 & RR \\
\hline $\begin{array}{ll}\mathrm{k} \\
38548\end{array}$ & T. machavav. Palaeoimereticum, Georgia & 5 & $\mathrm{RR}$ \\
\hline $\begin{array}{ll}\mathrm{k} \\
45546\end{array}$ & T. speltavav. Subbartiaricum, Iran & 10 & $\mathrm{RR}$ \\
\hline $\begin{array}{ll}\mathrm{k} \\
45817 \\
\end{array}$ & T. speltavav. Subbartiaricum, Iran & 10 & $\mathrm{RR}$ \\
\hline $\begin{array}{l}\mathrm{k} \\
45819\end{array}$ & T. speltavav. Subbartiaricum, Iran & 10 & RR \\
\hline $\begin{array}{ll}\mathrm{k} \\
46136 \\
\end{array}$ & T. speltavav. Asinegletum, asirecens, Algeria & 5 & $\mathrm{RR}$ \\
\hline $\begin{array}{l}\mathrm{k} \\
47010\end{array}$ & T. speltavav. Subbartiaricum, Iran & 5 & RR \\
\hline
\end{tabular}

${ }^{1} \mathrm{RR}$ - high resistance (grade of lesion $<5 \%$ )

${ }^{2} \mathrm{R}$ - practical resistance (grade of lesion in the range of 5-15\%); 
These varieties may act as genetic sources for the development of new wheat varieties that are resistant to Septoria leaf spot.

Using molecular markers, Lr genes were identified in 65 samples from the VIR collection and 14 wheat breeding lines created in I. V. Michurin Federal Research Center. These varieties combine resistance to brown rust with a complex of other positive characteristics. As a result of screening, the samples under study showed the presence of the following genes: Lr9, Lr19, Lr24, Lr 34, Lr1, Lr10, Lr20, Lr26. Among the breeding materials of I. V. Michurin Federal Research Center, the prevalence of lines with gene Lr19 in combination with ineffective genes $\operatorname{Lr} 10, \operatorname{Lr} 20$ and $\operatorname{Lr} 26$ was observed.

Each year, the laboratory employees carry out work on the selection of new highly effective sources and donors of spring soft wheat resistance adapted to zonal conditions. The investigation is primarily focused on the creation of varieties that are resistant to biotic and abiotic stress factors with a combination of economically valuable features.

Thus, in 2020, 10 combinations of crosses were made. Lr44, Lr45, Lr46, Lr47, Lr52 monogenic lines were applied as genetic donors. The other were taken from recipients. They were adapted to the conditions of the zonal zoned varieties: KVS Aquilon, KVS Torridon, Cornetto.

Estimation of the source material and spring soft wheat varieties created in the branch by the traditional selection method is analysed. The most precious genotypes were transferred to breeding nurseries. The priority characteristics and properties were mainly the degree of resistance to phytopathogens and yield indicators.

In order to conduct further breeding studies, 630 lines were selected, including 405 breeding lines resistant to brown rust and 136 - resistant to Septoria leaf spot, with group resistance to these pathogens - 89. They were taken from breeding nurseries and were of rising generation.

In terms of yield at the standard level (Favorit and Cornetto), 11 breeding numbers were identified in the nurseries of older generations (Table 2).

Table 2. Immunological characteristics and crop productivity of breeding lines, 2020.

\begin{tabular}{|c|c|c|c|c|c|c|c|}
\hline \multirow[t]{3}{*}{ Variety, line } & \multicolumn{4}{|c|}{ Diseases susceptibility } & \multicolumn{3}{|c|}{ Yield } \\
\hline & \multirow{2}{*}{$\begin{array}{l}\text { Brown } \\
\text { rust, } \\
\text { type/int } \\
\text { ensity }\end{array}$} & \multirow{2}{*}{$\begin{array}{l}\text { Septoria lea } \\
\text { spot, } \\
\%\end{array}$} & \multicolumn{2}{|c|}{ Smut } & \multirow[t]{2}{*}{$\mathrm{c} / \mathrm{ha}$} & \multirow{2}{*}{$\begin{array}{c} \pm \text { St } \\
\text { Favorit }\end{array}$} & \multirow{2}{*}{$\begin{array}{c} \pm \mathrm{St} \\
\text { Cornetto }\end{array}$} \\
\hline & & & $\begin{array}{c}\text { Dust, } \\
\%\end{array}$ & $\begin{array}{c}\text { Stinkin } \\
\mathrm{g}, \%\end{array}$ & & & \\
\hline \multicolumn{8}{|c|}{ Pre-variety testing } \\
\hline L-8074(11) & 1 unit & 10 & 0 & 1,0 & 0,5 & $+0,03$ & $-0,02$ \\
\hline L 8074(19) & $1 / 5$ & 20 & 1,3 & 0,0 & 0,51 & $+0,04$ & $-0,01$ \\
\hline L 8083(27) & $2 / 10$ & 20 & 0,5 & 0,0 & 0,46 & $-0,01$ & $-0,06$ \\
\hline L $8083(28)$ & $2 / 5$ & 30 & 1.2 & 0.0 & 0,47 & 0 & $-0,05$ \\
\hline L 8107(35) & 1unit & -10 & - & 0,0 & 0,45 & $-0,02$ & $-0,07$ \\
\hline L 8114(40) & $1 / 5$ & 30 & 0,0 & 0,0 & 0,53 & $+0,06$ & $+0,01$ \\
\hline Favorit St & $3 / 40$ & 40 & 10.0 & 12.1 & 0,47 & - & $-0,05$ \\
\hline Cornetto St & $3 / 20$ & 30 & - & - & 0,52 & $+0,05$ & - \\
\hline \multicolumn{8}{|c|}{ Competition variety testing } \\
\hline $\begin{array}{l}\text { In memory of } \\
\text { Plakhotnik }\end{array}$ & 0; 1un. & 20 & 0,0 & 0,0 & 0,51 & $+0,004$ & $-0,01$ \\
\hline L 8073 & $1 / 5$ & 10 & 1,0 & 0,0 & 0,51 & $+0,04$ & $-0,01$ \\
\hline L 8114 & $2 / 5$ & 15 & 10,0 & 0,1 & 0,53 & $+0,06$ & $+0,01$ \\
\hline L 8260 & $1-2 / 10$ & 15 & 0,0 & 0,0 & 0,55 & $+0,08$ & $+0,03$ \\
\hline L 8252(b) & $1 / 5$ & 10 & 0,0 & 0,1 & 0,52 & $+0,04$ & 0 \\
\hline L 2589(06) & $2 / 10$ & 20 & 1,0 & 0,5 & 0,54 & $+0,07$ & $+0,02$ \\
\hline Favorit St & $3 / 40$ & 40 & 10.0 & 12.1 & 0,47 & - & $-0,05$ \\
\hline Cornetto St & $3 / 20$ & 30 & - & - & 0,52 & $+0,05$ & - \\
\hline
\end{tabular}


In 2019, the State Commission for Variety Testing of Agricultural Crops received a variety of strong spring soft wheat in Memory of Plakhotnik, which is resistant to environmental stress factors and outperforms the standard variety Favorit in terms of yield. The variety is lutescens. Yield of the variety $-4.11 \mathrm{t} / \mathrm{ha}$; fibrin - 33.3; FDM - 58 .

\section{Conclusion}

In the selection material of spring wheat, as a result of targeted work to improve the effectiveness of breeding resistant varieties to pathogens of particularly harmful diseases, breeding lines and numbers that combine resistance to environmental stress factors (brown rust, Septoria leaf spot, dust and stinking smut) with a complex of other positive signs and features, primarily productivity and adaptability to the conditions of the Central Black Earth Economic Region, were identified and selected as potential genetic sources and donors.

As a result of samples screening in the collection of I. V. Michurin Federal Research Center, the following genes $\operatorname{Lr} 9, \operatorname{Lr} 19, \operatorname{Lr} 24, \operatorname{Lr} 34, \operatorname{Lr} 1, \operatorname{Lr} 10, \operatorname{Lr} 20, \operatorname{Lr} 26$ are revealed. Within the selection material, the prevalence of lines with the Lr19 gene in combination with inefficient genes $\operatorname{Lr} 10, \operatorname{Lr} 20$ and $\operatorname{Lr} 26$ was found.

Each year, the laboratory employees carry out work on the selection of new highly effective sources and donors of spring soft wheat resistance adapted to zonal conditions.

A variety of spring soft wheat in Memory of Plakhotnik was given to the State Commission for Testing and Protection of Breeding Achievements.

\section{Acknowledgements}

This investigation was performed and published with the support of the Regional Competition "Grants to support applied research of young scientists in 2020" "Study of ways to prevent epiphytotic development of wheat diseases in the conditions of the Central Black Earth Economic Region (on the example of Septoria leaf spot, brown rust, dust and stinking smut)" Project No. 27-MU-20 (02)

\section{References}

1. V. Shamanin, S. Shepelev, V. Pozherukova, E.I. Gultyaeva, T. Kolomiets, E. Pakholkova, A. Morgumov, Cr. Prot., 121, 7 (2019)

2. E.I. Gultyaeva, E.R. Shreyder, I.Yu. Kushnirenko, E.L. Shaydayuk, N.M. Kovalenko, Evaluation of advanced bread spring wheat lines for field and seedling resistance to foliar pathogens (BIO Web of Conferences. II International Scientific Conference "Plants and Microbes: The Future of Biotechnology", 2020)

3. E.I. Gultyaeva, S.N. Sibikeev, A.E. Druzhin, E.L. Shaydayuk, Selskokh.biolog, 55(1), 27 (2020)

4. S.N. Sibikeev, A.E. Druzhin, E.I. Gultyaeva, A.A. Yankovskaya, Ross. selskokhoz. nauk., 4, 10 (2020)

5. Methodological guidelines for the ways of evaluation and selection of the initial material for the creation of wheat varieties resistant to brown rust (2012)

6. J.-W. Qiu, A.C. Schürch, N. Yahiaoui, L.-L. Dong, H.-J. Fan, Z.-J. Zhang, B. Keller, H.Q. Ling, Theor Appl Genet, 115, 159 (2007)

7. S.K. Gupta, A. Charpe, S. Koul, et al., Genome, 48(5), 823 (2005)

8. J. Chelkowski, L. Golka, L. Stepien, J.Appl. Genet., 44, 323 (2003) 
9. R. Prins, G.F. Marais, Z.A. Pretorius et al., Theor. Appl. Genet., 95, 424 (1997)

10. S.K. Gupta, A. Charpe, K.W. Prabhu, O.M.R. Hague, Theor. Appl. Genet., 113, 1027 (2006)

11. C. Neu, N. Stein, B. Keller, Genome, 45(4), 737 (2002)

12. MASWheat, http://maswheat.ucdavis.edu

13. R. Mago, H. Miah, G.J. Lawrence et al., Theor. Appl. Genet., 112, 41 (2005)

14. R. Mago, W. Spielmeyer, G.J. Lawrence et al., Theor Appl Genet., 104(8), 1317 (2002)

15. D.P. Cherukuri, S.K. Gupta, A. Charpe et al., Euphytica, 143, 19 (2005)

16. J.D. Procunier, R.E. Knox, A.M. Bernier, M.A. Gray, N.K. Howes, Genome, 40(2), 176 (1997)

17. E.S. Lagudah, H. McFadden, R.P. Singh et al., Theor. Appl. Genet., 114, 21 (2006)

18. R. Mago, P. Zhang, H.S. Bariana et al., Theor. and Appl. Genet., 124, 65 (2009)

19. M. Helguera, I.A. Khan, J. Dubcovsky, Theor. and Appl. Genet., 101 (4), 625 (2000)

20. E. Pestsova, M.W. Ganal, M.S. Röder, Genome, 43(4), 689 (2000)

21. MASWheat, http://maswheat.ucdavis.edu

22. D.B. Dorokhov, E. Kloke, Genet., 33(4), 443 (1997) 